\title{
The Manifestation and the Change of Lithuanian Academic Youth's National Identity
}

Dalia Antiniené $\dot{1}^{1}$ Giedrè Širvinskienè $\dot{1}^{1,2}$, Rosita Lekavičiené ${ }^{3}$

1 Lithuanian University of Health Sciences, Faculty of Public Health Sciences, Tilžès g. 18, LT-47181 Kaunas, Lithuania, dalia.antiniene@lsmuni.lt, giedre.sirvinskiene@lsmuni.lt

2 Lithuanian University of Health Sciences, Health Research Institute, Tilžès g. 18, LT-47181 Kaunas, Lithuania, giedre.sirvinskiene@lsmuni.lt

3 Kaunas University of Technology, Faculty of Social Sciences, Arts and Humanities, A. Mickevičiaus g. 37, LT-44244 Kaunas, Lithuania, rosita.lekaviciene@ktu.lt

\begin{abstract}
This article deals with the peculiarities of understanding the attitudes of national identity among Lithuanian academic youth. The study took place in 2003, 2008, and 2018. Results revealed that the national identity scale can be very wide, starting from an extreme national chauvinism that emphasizes national exclusivity to cosmopolitanism that ignores national culture, traditions, patriotism.
\end{abstract}

Keywords: national identity, attitudes, nationalism, traditional nationality, modern nationality, ethnocentrism, anti-ethnocentrism.

\section{Introduction}

In 1968, Erikson noticed that it is meaningful to separate different areas of identity (Erikson, 1968). S. L. Archer (1992) identified ideological identity, and J. Marcia (1993) noted professional, attitudes and interpersonal relationships areas. B. Newman and P. Newman (1979) claimed that an integrated personal identity consists of gender, moral and political identities.

National identity is also considered one of the aspects of personal identity (Miller, 1993; Tamir, 1996; Hanson \& O’Dwyer, 2019). Interpretations of the concepts of nationality and national identity are constantly evolving and acquiring different meanings as 
society becomes more and more complex. The concept of identity has received increased attention in the scientific literature in the last decades. The importance of research on national identity is strengthened by multiple facts and changes in economic, political or cultural contexts like ethnic conflicts, wars, intensive migration, external threat perception, accelerating globalization, as well as the worries of citizens regarding the levelling of nationalities. Along with cultural changes in modern society, identity becomes more problematic and challenging. Some authors conclude that nowadays, in the era of globalization, national identity undergoes a crisis, which arises in political, economic and cultural levels (Zhuojun \& Hualing, 2014; Ray, 2018). At the same time, there are further different manners to construct this identity. Now young adults can form their identity via a greater number of pathways compared with earlier times; the process is more chaotic and also involves more individualized "strategies" which can be part of a continual struggle with one's inner conflicts and resources (Cote \& Levine, 2008).

National identity can be defined as a dynamic, multidimensional construct of individual reflection, and awareness of one's place and role in the world (Phinney, 1990; Abell, 2006; etc.). Researchers have determined several dimensions of attitudes reflecting national identity as respect for the nation's history, heritage protection, attachment to the place of residence, pride in national sports' victories, attitudes towards national minorities, etc. (Kosterman \& Feshbach, 1989; Abell et al., 2006; Ariely, 2019). Some authors see national identity as a combination of four aspects - like institutional identity, interest identity, cultural identity, and non-national community identity - and point out the differences from ethnocultural identity (Zhuojun \& Hualing, 2014).

Some authors distinguish different concepts of national identity: ethnic, multicultural and civic (Brown, 2007; Korostelina, 2008). In terms of the ethnic concept of national identity, some people perceive their nation as mono-ethnic, monolingual, and is built around a core ethnic community into which ethnic minorities should assimilate. Other people view their nation as multicultural, with equal rights, elements of autonomy and self-governance for all ethnic groups, where ethnic minorities should be guaranteed resources to maintain their ethnic culture and communities. Still, other people see their citizenship as a civil contract between a person and the state concerning their rights and obligations; the constitution, rules of law and civic responsibility are seen as the main features of the nation, and such people see ethnicity as not significant. (Brown, 2007; Korostelina, 2008).

National identity is not static and it is important to take into account that social, political and economic processes and context can have a huge impact on national identity constructions. For example, after European integration, a question about the degree of European identity which holds citizens and its association with national identity emerges in Europe. Studies show that despite these changes, European identity has not displaced national identities, but for a significant share of EU citizens, European identity exists alongside a national identity (Fligstein, 2012). According to the Eurobarometer survey, 
most of the EU population views itself as having a mainly national, and not a European identity: $90 \%$ of EU respondents (and 94\% of Lithuanian respondents) see themselves as more national than European (Eurobarometer, 2014). Studies of ethnic minorities in Central and Eastern Europe also reveal a link between European and national identities (Tchistiakova \& Waechter, 2016), ethnic identities, and national identities of their country of residence (Waechter, 2016). Globalization has resulted in the expansion of transnational, postcolonial and global aspects of identity constructions; however, as Rembold and Carrier (2011) note, national attachments also remain important, Moreover, analysis of empirical data show that increased economic integration into the global economy, mobility and communication enhance rather than diminish national attachments (Rembold \& Carrier, 2011).

Research shows that conceptions of national identity are sometimes explicitly articulated by citizens, or are sometimes implicit, being revealed indirectly. People's conceptions of national character are essentially stereotypes, which may be descriptive in nature, where citizens are viewed as prototypical based on observation, or they may be prescriptive in nature, where citizens are idealized as "true" citizens. Prescriptive stereotypes are ones that perceivers may be motivated to protect and defend (Yogeeswaran \& Dasgupta, 2014).

National identity influences attitudes and behavior towards different ethnic groups within their own nation and their approach to other nations. Studies of national identities among minorities show that national identity characteristics and their relationship with behavior and attitudes are not the same across nations. For example, a study of Russian and Crimean Tatars' ethnic minorities' national identity in Ukraine showed differences in these groups in the aspect of readiness to fight. For powerful and numerous minorities, such as Russians, the ethnic concept of national identity strengthens the willingness to fight for a privileged position within society; a multicultural concept reduces their readiness to fight, because they expect to obtain major benefits. For small minorities, such as Crimean Tatars, the ethnic concept of national identity encourages assimilation and reduces willingness to fight; a multicultural concept evokes competition with other ethnic groups for rights and social and economic position within society (Korostelina, 2008). A study found that stronger national identification was related to a greater sense of psychological ownership of the country one lives in, which, in turn, was associated with less positive attitudes towards immigrants (Brylka, Mähönen \& Jasinskaja-Lahti, 2015). National identity has an impact also on other aspects of human behavior and attitudes. A relationship between national identity and consumer behavior was also documented people who have a high national identity, have higher consumer ethnocentrism, which is related to a willingness to buy national products (Nguyen-Hau Le et al., 2013; Carvalho, Lunab, \& Goldsmith, 2019).

In order to better understand the formation of national identity in Lithuania, it is important to have a look at the change in national identity in the context of various historical events over a longer period of time. Over the past few decades Lithuania has gone 
through a lot of historical, political, economic and social changes, connected to both the relationship with Russia and the formation of closer relationship with the West; all this could have had impact on national identity constructions in Lithuania. After regaining independence in 1990, a new generation of current young adults was born and raised. Their national identity has formed in totally different circumstances compared with those of their parents. Our study started in 2003, more than 10 years after regaining political state sovereignty. Soon after the study began, in 2004 Lithuania became a member of the European Union and NATO. This happened with the strong agreement of the society, expressed in a referendum in $2003-91.07 \%$ of Lithuania's citizens voted for the country's admission into the $\mathrm{EU}$ out of the $63,37 \%$ of voting citizens. After that time, European status in the country was strengthened through the formation of European institutions, the harmonization of legal acts, market liberalization, and reforms to its administrative systems (Mazylis, 2013), which also may have had an impact on national identity formation, as international organizations, creating certain legal regulations and monitoring their realization, are also considered as factors influencing national identities (Sadowski, 2008). However, along with the open possibilities to move, intensive emigration became a matter of serious concern for such a small country as Lithuania (Rakauskiené, 2013). Alongside the economic crisis in 2007-2011, a bigger emigration wave started in Lithuania (Sipavienè \& Stankūniené, 2011), even though the crisis was expected to also have positive outcomes, such as increased European political cooperation (Fligstein, 2012). Society's perceived political security also underwent some changes during the study period. In 2014 a conflict between Russian and Ukraine began, and a representative study in Lithuania showed that after the conflict began, only one third (31.8\%) of the inhabitants of Lithuania reported feeling secure considering the conflict (Gečienè, 2015).

The main aim of this study was to describe the content of Lithuanian students' attitudes reflecting national identity to analyze the peculiarities of and changes in their expression between 2003, 2008 and 2018.

\section{Materials and methods}

\section{Subjects}

The results of the study of attitudes that reflect national identity were obtained from the Lithuanian academic youth population. Subjects were included in the sample according to the quota sampling method, maintaining the natural proportions of the general Lithuanian student population. When choosing slots, the following factors were considered: geography, scientific field and level, the prestige of the institution, and others. Students of universities and colleges were interviewed.

The study of attitudes that reflect national identity took place in 2003, 2008, and 2018. Data was being collected with the intention to present all Lithuanian high school students' 
proportions according to their gender, age, institutional and educational level. In 2003, 712 respondents - active Lithuanian students at universities and colleges - within the target sample were interviewed. The basic demographic characteristics of the student sample are as follows: $39.6 \%$ male, $60.4 \%$ female (according to the Lithuania Statistics Department, male and female proportions in Lithuanian high schools each year vary approximately $35 \%$ males and $65 \%$ females), ranging in age from $18-29$ years, $M=21.8$, $\mathrm{SD}=4.84$ years.

For data comparison and to ensure a better statistical dispersion of attributes as well as to meet strict requirements for psychometric instruments, more respondents and several control-contrast groups were included in the sample in 2003 when the questionnaire was created. They consisted of senior secondary school, gymnasium, and adult education center students, young unemployed people, political prisoners, and exiles, people over 40 years of age (of different socioeconomic status, different professions, etc.). The control-contrast sample consisted of 290 interviewees ( $29 \%$ of the general sample). In 2003, 1002 subjects were interviewed in total.

In the studies conducted in 2008 and 2018, university and college students were also interviewed. The study's geography remained the same; however, the number of respondents went down. As was mentioned earlier, it could have been affected by the verified statistical reliability of the instrument. On the other hand, a drastic change in the number of students in Lithuania could have also had an impact. In total, 515 students were interviewed in the repeated study in 2008. The most important student sample characteristics are as follows: $37 \%$ male, $63 \%$ female, ranging in age from 18-31 years, $\mathrm{M}=21.4, \mathrm{SD}=4.93$ years. In the 2018 study, a total of 480 students were interviewed, $36 \%$ of which were male, and 64\% were female, ranging in age from 18-30 years, $\mathrm{M}=21.9, \mathrm{SD}=4.89$ years.

Summarizing the study sample characteristics, it can be stated that based on the type of study, variety of groups, sample size, and conformity of the sociodemographic characteristics to the population's statistical indicators, the sample can be held as conditionally representative and as meeting the requirements of the study.

\section{Study methodology}

Because the science of psychology still doesn't possess commonly defined indicators (constituents) of national identity, and a more or less common method to study national identity hasn't been determined, in this study it has been decided to reveal this theoretically abstract and complex sociopsychological phenomenon through the prism of a social attitude study. In the view of some researchers, national identity attitudes are formed in a consistent order starting from a neutral point of view towards nationality, in two different directions either towards cosmopolitanism or nationalism (Dekker et al., 2003). Because the attitude spectrum can be very wide, the aim of constructing the study instrument was to cover as many indicators reflecting national identity as possible. In 
this way, the attitude scale comprised 33 test steps, the semantics of which were oriented towards uncovering various, fairly different aspects of national identity.

In constructing the questionnaire, a psychometric survey approach was chosen. The aim was for the respondents to reveal their national identity-related attitudes indirectly. For this reason, the statements that reflect these attitudes were not arranged sequentially in the questionnaire in terms of content. Additionally, when using this approach, isolated statements are not used; instead, it operates through indices, scales, and secondary scales (subscales). In preparing the instrument, a five-point Likert scale was chosen, with answers ranging from 4 , "completely agree" to 0 , "completely disagree". Thirty-three statements were later used to create scales using factor validation. The initial statements were condensed into 11 subscales and 5 scales using factor analysis.

The empirical study of attitudes that reflect the national identity of Lithuanian students was conducted using an anonymous survey. The survey was conducted in auditoriums, in groups of 25-30 people. Filling out the questionnaire took about 30 minutes; the response ratio was $92 \%$.

For a more thorough look at the questionnaire design and psychometric quality indicators, please see the article titled Attitudes reflecting national identity of Lithuanian students in the journal Humanities and Social Sciences (Antiniené, 2012).

\section{Results}

Factor validation was used as the main method of creating scales in the study. The data of the entire sample $(\mathrm{N}=1002)$ obtained in 2003 was used to create the scales. The rest of the study results were obtained exclusively in the student population. More about the factorial structure and psychometrical quality characteristics of attitudes that reflect national identity can be learned from the previously mentioned article, published in the Humanities and Social Sciences journal. However, for clarity, the complex structure of national identity attitudes gained through factorial analysis is presented in Figure 1. 


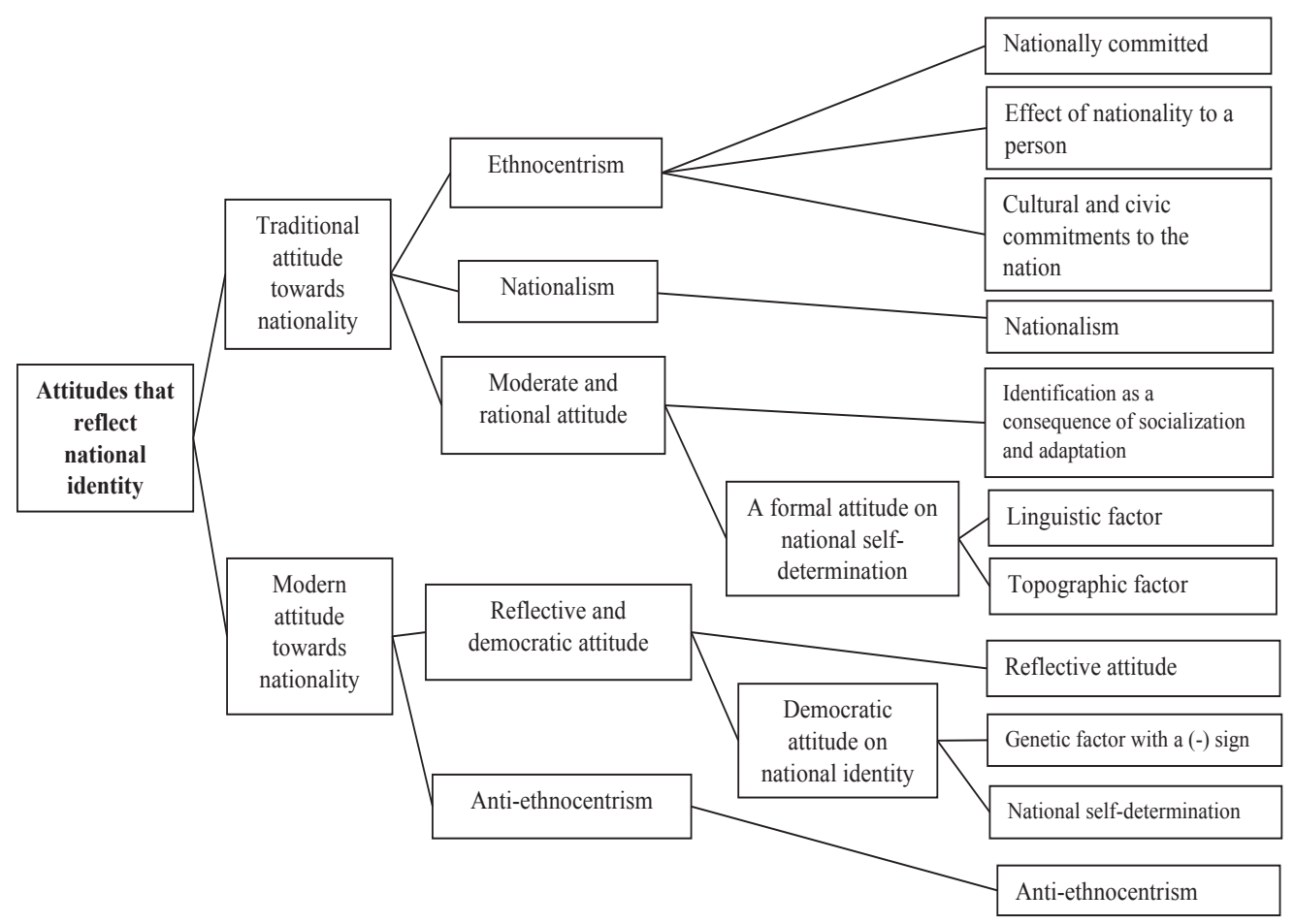

Figure 1. Complex struxture of national identity attitudes

\section{Indicators of subscale (index) internal consistency}

In order to verify the psychometric validity of the questionnaire, a subscale reliability analysis was repeated in 2008 and 2018. After repeating the study, the internal consistency, resolution ( $\mathrm{r} / \mathrm{itt})$, and the minimal and maximal intercorrelation between the statements of each scale of the questionnaire were tested. The data obtained can be seen in Table 1 .

Aside from the five subscales presented in Table 1, the study used more subscales: "the effect of nationality to a person", "nationalism", "a formal attitude on national self-determination" (which is composed of "linguistic" and "topographic" elements), and "a democratic attitude on national identity" (which is composed of a "genetic" factor with a (-) sign and the "national self-determination" subscales). Because these subscales comprise only one or two items (see Fig. 1), their internal consistency was not checked. 
Table 1

Internal consistency of attitudes that reflect national identity subscales (research data obtained in 2003, 2008 and 2018 year)

\begin{tabular}{lcccc}
\hline \multicolumn{1}{c}{ Subscale (index) name } & Cronbach $\boldsymbol{\alpha}$ & $\begin{array}{c}\text { Mean } \\
\text { (inter-item } \\
\text { correlations) }\end{array}$ & $\begin{array}{c}\text { Min } \\
\text { (item-total } \\
\text { correlation r/itt) }\end{array}$ & $\begin{array}{c}\text { Max } \\
\text { (item-total } \\
\text { correlation r/itt) }\end{array}$ \\
\hline $\begin{array}{l}\text { Nationally committed } \\
\text { (4 items) }\end{array}$ & $0.67 / 0.58 / 0.74$ & $0.36 / 0.26 / 0.42$ & $0.33 / 0.33 / 0.38$ & $0.57 / 0.42 / 0.62$ \\
\hline $\begin{array}{l}\text { Cultural and civic commit- } \\
\text { ments to the nation (9 items) }\end{array}$ & $0.84 / 0.57 / 0.86$ & $0.37 / 0.29 / 0.55$ & $0.34 / 0.28 / 0.36$ & $0.67 / 0.50 / 0.71$ \\
\hline $\begin{array}{l}\text { Reflective attitude (3 items) } \\
\text { Anti-ethnocentric (relatively }\end{array}$ & $0.65 / 0.66 / 0.67$ & $0.38 / 0.39 / 0.41$ & $0.42 / 0.42 / 0.43$ & $0.51 / 0.54 / 0.59$ \\
$\begin{array}{l}\text { cosmopolitanism) attitudes } \\
\text { (4 items) }\end{array}$ & $0.53 / 0.51 / 0.54$ & $0.22 / 0.28 / 0.26$ & $0.20 / 0.20 / 0.22$ & $0.44 / 0.41 / 0.42$ \\
\hline $\begin{array}{l}\text { Identification as a conse- } \\
\text { quence of socialization and } \\
\text { adaptation (5 items) }\end{array}$ & $0.71 / 0.74 / 0.72$ & $0.33 / 0.36 / 0.34$ & $0.44 / 0.42 / 0.45$ & $0.50 / 0.57 / 0.51$ \\
\hline
\end{tabular}

Testing theory indicates an acceptable coefficient variation interval of $0.5<a<1$. In some cases the subscales have somewhat low internal consistency, e.g. "anti-ethnocentric" (conditionally cosmopolitan) attitude subscale, though that is affected by the low number of diagnostic statements in any given subscale. It is emphasized in the scientific literature that the Cronbach's alpha internal consistency indicator depends on the length of the test. It can be considered that were the number of stimuli to increase, the aforementioned indicator would rise as well.

One of the statistical parameters that reflect a measurement instrument's internal consistency is the items' resolution or differential power coefficient $r$ /itt. The resolution coefficient results of the test stages are not high, but sufficient. Also, considering the factorial loading of the 2003 study, it can be said that after the second and third measurements, the test's psychometric quality remained acceptable (satisfactory).

\section{A multivariate model for analyzing attitudes that reflect national identity}

In searching for a more generalized structure in student national identity attributes, a multilevel factor analysis was performed along with the national identity attitude subscale evaluations. Some subscales were combined and some categories that interfered with the factor analysis were eliminated altogether.

The final data of the analysis of attitudes that reflect national identity allow discussion regarding their two-dimensional structure (see Table 2). Attitudes are polarized into two components - "traditional" and a "modern" outlook on national identity. It must be noted that the statistical suitability of the factor analysis data is tolerable. The KMO indicator at 0.50 is not high, but the indices of explained spread are sufficient. The entire two-factor 
model explains $51.1 \%$ of the studied attribute spread. The explained spread of individual factors is rather high at $23.3 \%$ and $27.8 \%$. Most of the factor weights obtained from the model are also high enough at $0.53 \leq_{\mathrm{r}} \leq 0.74$. This shows that the created categories are suitable because they meet the methodological norm of construct validity.

Table 2 .

Final data of attitudes that reflect national identity multi-factor analysis

\begin{tabular}{|c|c|c|c|c|}
\hline \multirow{2}{*}{$\begin{array}{c}\text { Factors } \\
\text { Scales (indexes) }\end{array}$} & \multicolumn{2}{|c|}{$\begin{array}{c}\text { Factor } 1 \\
27,8 \% \\
\end{array}$} & \multicolumn{2}{|c|}{$\begin{array}{c}\text { Factor } 2 \\
23,3 \%\end{array}$} \\
\hline & $\begin{array}{l}\text { „Traditional } \\
\text { approach to } \\
\text { nationality“" } \\
\text { L } \\
\end{array}$ & $\begin{array}{c}\text { Cronbach } \\
\alpha\end{array}$ & $\begin{array}{l}\text { „Modern } \\
\text { approach to } \\
\text { nationality“" } \\
\text { L } \\
\end{array}$ & $\begin{array}{c}\text { Cronbach } \\
a\end{array}$ \\
\hline "Ethnocentrism" (15 items) & 0.74 & 0.88 & -0.35 & \\
\hline "Nationalism" (2 items) & 0.56 & - & -0.02 & \\
\hline $\begin{array}{l}\text { "Moderate and rational } \\
\text { approach" (7 items) }\end{array}$ & 0.53 & 0.71 & 0.16 & \\
\hline $\begin{array}{l}\text { "Reflective and democratic } \\
\text { approach" (5 items) }\end{array}$ & 0.39 & & 0.72 & 0.50 \\
\hline $\begin{array}{l}\text { "Anti-ethnocentrism } \\
\text { (conditional cosmopolitan- } \\
\text { ism)" (4items) }\end{array}$ & -0.33 & & 0.71 & 0.53 \\
\hline
\end{tabular}

The decisive factor in justifying the suitability of a factor analysis is the ability to interpret variables clustered in a factor theoretically. The resulting model satisfies this condition. It is both theoretically meaningful and statistically pure. In Table 2 it can be seen that the variables contained in the first factor semantically reflect a "traditional" outlook on national identity, and the variables contained in the second factor reflect the "modern" outlook. The first factor contains such scales as "ethnocentricity" (obtained by combining "ethnically motivated position", "the effect of national identity on the person", and "cultural and civic obligations to the nation" subscales (Cronbach's alpha $=0.88$ )), "nationalistic" and "moderate and rational attitude" towards national self-determination (obtained by combining "identification as socialization and adaptation outcomes", "linguistic element”, and "topographic element” subscales (Cronbach's alpha $=0.71)$ ). The second factor contains such scales as "reflexive and democratic outlook" (obtained by combining "reflexive outlook", "genetic element with a (-) sign", and "national self-determination" subscales (Cronbach's alpha $=0.50)$ ), and "anti-ethnocentrism (conditional cosmopolitanism)" (Cronbach's alpha $=0.53)$. It must be noted that scales were given 
relative or working titles, the connotations of which can differ from the traditional meanings used in science.

\section{The hierarchical structure of attitudes that reflect national identity}

Each statement in the national identity attitude subscale, as well as every scale and subscale condensed by factor analysis, allows a particular national identity dimension to be evaluated. While presenting the study results, and in order to follow the length requirements of a scientific article, individual test statements are omitted and only the general scale ratings, obtained in studies done over a decade ago and later, are presented.

The statistical data for agreement with national identity attitude scales, as well as the agreement ratings are presented in Tables 3, 4, and 5. To present the study results, the summarized scale ratings of all three studies are shown (i.e., the agreement percentages of indices that were obtained from individual statements through factorization, from highest to lowest). Traditionally, psychometric studies use psychometric index averages, but a Likert scale-based index average has a drawback as a measure: it is a purely quantitative measure which is hard to picture and interpret qualitatively. As shown mathematically and empirically by Borg and Gabler, instead of using a scale average, which from an interpretational standpoint is rather inconvenient, the percentage of average agreement to scale statements can reasonably be used. For this reason, the percentage frequencies attributed to each statement's agreement category are aggregated (disagreement percentages are eliminated from the aggregation procedure), and an average agreement percentage is derived from the resulting individual statement percentage ratings.

The scale ratings of the 2003 study are presented in Table 3 . The minimum and maximum agreement shown here indicates "yes" choices for individual scale statements and reflects the respondents' range of agreement with the statements.

Table 3.

Rating of students approval of nationality attitudes (2003 year)

\begin{tabular}{|c|c|c|c|c|c|c|c|}
\hline Scale names & $\begin{array}{l}\text { Number of } \\
\text { items }\end{array}$ & Mean & $\begin{array}{c}\text { St. } \\
\text { deviation }\end{array}$ & $\begin{array}{l}\text { St. } \\
\text { error }\end{array}$ & $\begin{array}{c}\text { Min. } \\
\text { approv. }\end{array}$ & $\begin{array}{c}\text { Max. } \\
\text { approv. }\end{array}$ & $\begin{array}{l}\text { Average } \\
\text { approv. }\end{array}$ \\
\hline & Units & $\mathbf{M}$ & SD & SE & $\%$ & $\%$ & $\%$ \\
\hline "Ethnocentrism" & 15 & 2.47 & 0.73 & 0.03 & 43.1 & 92.3 & 67.7 \\
\hline $\begin{array}{l}\text { "Reflective and } \\
\text { democratic } \\
\text { approach" }\end{array}$ & 5 & 1.09 & 0.67 & 0.02 & 9.9 & 86.7 & 53.3 \\
\hline $\begin{array}{l}\text { "Moderate and } \\
\text { rational approach" }\end{array}$ & 7 & 1.22 & 0.69 & 0.01 & 14.6 & 55.1 & 34.9 \\
\hline $\begin{array}{l}\text { "Anti-ethnocen- } \\
\text { trism (conditional } \\
\text { cosmopolitism)“" }\end{array}$ & 4 & 1.47 & 0.85 & 0.03 & 13.9 & 44.4 & 26.8 \\
\hline "Nationalism" & 2 & 1.46 & 1.06 & 0.03 & 8.4 & 26.4 & 17.4 \\
\hline
\end{tabular}


As can be seen, in 2003 the highest average agreement percentage is for "ethnocentrism", and the lowest is in the "nationalistic" outlook scale. A relatively high student agreement was seen for most "ethnocentrism" statements, which is reflected by the agreement minimum (43.1\%), which is higher than the maximum agreement for the statements of several other scales. It can be clearly seen in Table 3 that agreement with extreme national identity positions, i.e. "anti-ethnocentrism (conditional cosmopolitanism)" and "nationalistic outlook", is lowest. The decline in respondents agreeing with extreme attitudes perhaps suggests that these national identity attitudes require more complex personality and psychological processes than more moderate, i.e. intermediate, positions.

After performing a study of attitudes that reflect national identity five years later, the results were different. The summarized scale data can be seen in Table 4 .

Table 4 .

Rating of students approval of nationality attitudes (2008 year)

\begin{tabular}{|c|c|c|c|c|c|c|c|}
\hline Scale names & $\begin{array}{l}\text { Number of } \\
\text { items }\end{array}$ & Mean & $\begin{array}{c}\text { St. } \\
\text { deviation }\end{array}$ & $\begin{array}{l}\text { St. } \\
\text { error }\end{array}$ & $\begin{array}{c}\text { Min. } \\
\text { approv. }\end{array}$ & $\begin{array}{c}\text { Max. } \\
\text { approv. }\end{array}$ & $\begin{array}{l}\text { Average } \\
\text { approv. }\end{array}$ \\
\hline & Units & $\mathbf{M}$ & SD & SE & $\%$ & $\%$ & $\%$ \\
\hline "Ethnocentrism" & 15 & 1.56 & 0.39 & 0.02 & 46.1 & 89.3 & 69.0 \\
\hline $\begin{array}{l}\text { "Moderate and } \\
\text { rational approach" }\end{array}$ & 7 & 1. 52 & 0.30 & 0.01 & 24.5 & 62.5 & 41.5 \\
\hline „Nationalism“ & 2 & 1.09 & 1.02 & 0.02 & 9.9 & 86.7 & 27.2 \\
\hline $\begin{array}{l}\text { "Anti-ethnocen- } \\
\text { trism (conditional } \\
\text { cosmopolitism)" }\end{array}$ & 4 & 1.47 & 0.77 & 0.03 & 13.9 & 44.4 & 27.2 \\
\hline $\begin{array}{l}\text { "Reflective and } \\
\text { democratic } \\
\text { approach" }\end{array}$ & 5 & 1.46 & 0.62 & 0.03 & 8.4 & 26.4 & 20.9 \\
\hline
\end{tabular}

The "nationalistic" outlook on national identity should be noted in Table 4. Its average agreement grew, exceeded agreement with the "reflexive and democratic outlook", and became equal to the "anti-ethnocentric (conditionally cosmopolitan)" attitude scale. Five years later, a minor tendency towards a more nationalistic outlook on nationality can be seen. Changes can also be seen in the percentages of average agreement in the "moderate and rational outlook" scale. The outlook on nationality as a choice, i.e. the ratings of "reflexive and democratic outlook" towards nationality, declined by as much as 32.4 percentage points.

The results of the study done in 2018 can be seen in Table 5. By comparing average agreement percentages, a change in nationality attitudes can also be seen. 
Table 5.

Rating of students approval of nationality attitudes (2018 year)

\begin{tabular}{|c|c|c|c|c|c|c|c|}
\hline Scale names & $\begin{array}{l}\text { Number of } \\
\text { items }\end{array}$ & Mean & $\begin{array}{c}\text { St. } \\
\text { deviation }\end{array}$ & $\begin{array}{l}\text { St. } \\
\text { error }\end{array}$ & $\begin{array}{l}\text { Min. } \\
\text { approv. }\end{array}$ & $\begin{array}{l}\text { Max. } \\
\text { approv. }\end{array}$ & $\begin{array}{l}\text { Average } \\
\text { approv. }\end{array}$ \\
\hline & Units & $\mathbf{M}$ & SD & SE & $\%$ & $\%$ & $\%$ \\
\hline "Ethnocentrism" & 15 & 2.57 & 0.77 & 0.04 & 41.6 & 93.8 & 69.6 \\
\hline $\begin{array}{l}\text { "Moderate and } \\
\text { rational approach" }\end{array}$ & 7 & 1.08 & 0.29 & 0.02 & 20.0 & 62.4 & 46.0 \\
\hline $\begin{array}{l}\text { "Reflective and } \\
\text { democratic } \\
\text { approach" }\end{array}$ & 5 & 0.97 & 0.61 & 0.03 & 8.4 & 34.4 & 21.1 \\
\hline $\begin{array}{l}\text { "Anti-ethnocen- } \\
\text { trism (conditional } \\
\text { cosmopolitism)“" }\end{array}$ & 4 & 1.25 & 0.72 & 0.04 & 10.1 & 36.4 & 20.4 \\
\hline "Nationalism" & 2 & 1.15 & 1.03 & 0.06 & 10.9 & 17.8 & 14.4 \\
\hline
\end{tabular}

Table 5 shows an even higher "ethnocentric" attitude and diminished positions of extreme attitudes that are "anti-ethnocentric" and "nationalistic" attitudes.

It can be concluded that in all three sections of attitudes, the "ethnocentric" attitude towards nationality is most prevalent, but the structure of attitudes changes over time. It is interesting to note that the most significant changes were noticed in the 2008 study, whereas in the 2003 and 2018 studies, the acceptance of many of the attitudes among respondents is similar.

\section{Comparison of changes through different studies}

Identical questionnaires were used in the 2003, 2008, and 2018 studies, and the study design remained the same in constructing the scale and subscale structure. For these reasons, a non-parametric Kruskal-Wallis test was performed to compare the independent samples (see Table 6). By using this test, which subscale ratings differed significantly in the first, second, and third tests were determined.

In all scales the p-value was lower than the set level of significance (0.05), which shows statistically significant differences between national identity reflecting scale ratings in 2003, 2008, and 2018. As is known, higher values are given higher ranking averages; therefore, it is obvious which questionnaire scales are agreed with more in which study. Based on average rankings, it can be concluded that in recent years there has been more ethnocentrism and moderate views on national identity, while extreme national identity attitudes - nationalistic and anti-ethnocentric (cosmopolitan) positions - declined. On the other hand, there have been fewer people thinking about their national identity; i.e., national identity reflection has decreased. 
Table 6

Mean ranks of national identity scales. Kruscal-Wallis test

\begin{tabular}{|c|c|c|c|c|}
\hline Subscale names & Study year & Mean Rank & $\chi^{2}$ & $\mathrm{p} \leq$ \\
\hline \multirow{3}{*}{ „Ethnocentrism“ } & 2003 & 917.8 & \multirow{3}{*}{453.80} & \multirow{3}{*}{0.001} \\
\hline & 2008 & 366.7 & & \\
\hline & 2018 & 973.5 & & \\
\hline \multirow{3}{*}{$\begin{array}{l}\text { "Reflective and } \\
\text { democratic approach" }\end{array}$} & 2003 & 819.1 & \multirow{3}{*}{7.19} & \multirow{3}{*}{0.05} \\
\hline & 2008 & 774.7 & & \\
\hline & 2018 & 743.6 & & \\
\hline \multirow{3}{*}{$\begin{array}{l}\text { "Moderate and rational } \\
\text { approach" }\end{array}$} & 2003 & 753.7 & \multirow{3}{*}{31.96} & \multirow{3}{*}{0.001} \\
\hline & 2008 & 848.4 & & \\
\hline & 2018 & 882.8 & & \\
\hline \multirow{3}{*}{$\begin{array}{l}\text { "Anti-ethnocentrism } \\
\text { (conditional cosmo- } \\
\text { politanism)" }\end{array}$} & 2003 & 818.3 & \multirow{3}{*}{16.08} & \multirow{3}{*}{0.001} \\
\hline & 2008 & 810.6 & & \\
\hline & 2018 & 701.6 & & \\
\hline \multirow{3}{*}{ "Nationalism" } & 2003 & 807.3 & \multirow{3}{*}{42.95} & \multirow{3}{*}{0.001} \\
\hline & 2008 & 873.5 & & \\
\hline & 2018 & 654.7 & & \\
\hline
\end{tabular}

\section{Typology of attitudes that reflect national identity}

Using cluster analysis (K-means cluster analysis), the study attempts to identify specific statistical types of studying youth that occur according to two determined indicators of nationality attitudes - "modern" and "traditional" outlooks on national identity. Cluster analysis enables a grouping process of respondents to be performed in a way that differences within a cluster remain as small as possible, and between clusters as big as possible. In the current analysis, it is important to note that there is no predefined number of clusters; therefore, in each case there is a creative search of the existing differences. In other words, it is a dynamic statistic procedure in which potential cluster models, according to their content and quantity, are searched.

Clustering results obtained in 2003 are presented in Figure 2. It turned out that four groups of studying youth exist, profiled fairly differently based on their outlook on national identity. 


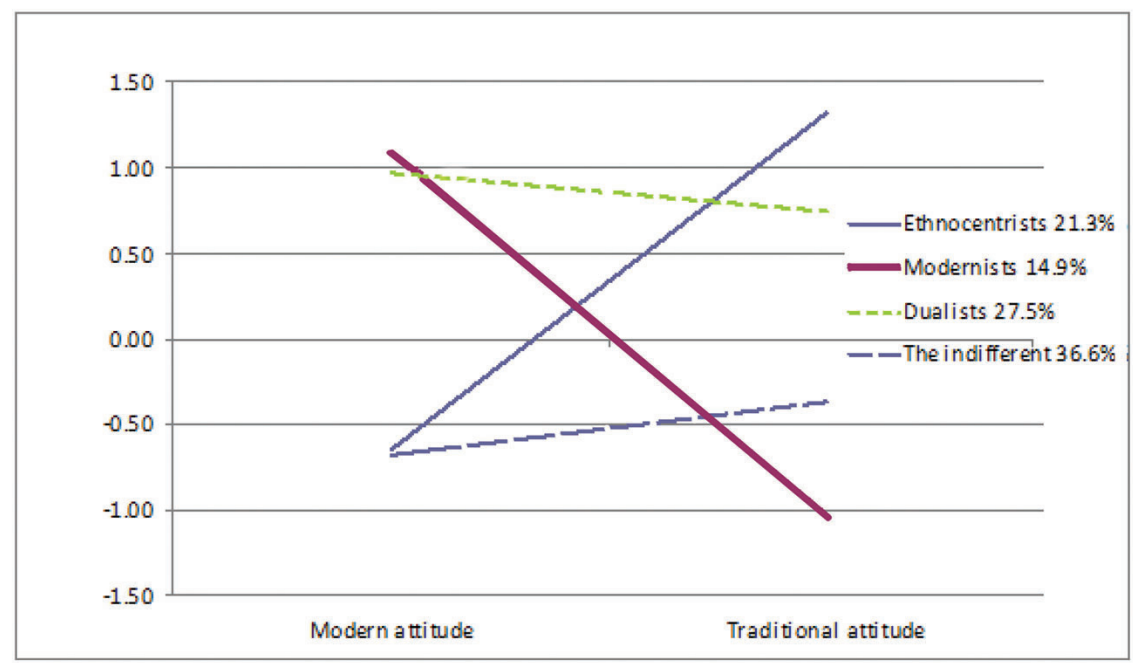

Figure 2. Statystical types of students, classified by their either modern or traditional approach to national identity (2003 year)

The group conditionally named as "modernists" is composed of the smallest number of subjects (14.9\%). In this group, the "modern" outlook on national identity is expressed strongly, and the "traditional" outlook weakly. Persons belonging to this type look at nationality in a somewhat superficial way. One fifth of all subjects (21.3\%) exhibit the opposite characteristics; this group is conditionally named as "ethnocentrists". They hold a "traditional" outlook on national identity, and their "modern" outlook is expressed weakly. This group is strongly nationally committed, recognizes national values and fosters traditions. The student group which exhibits both "modern" and "traditional" outlooks on nationality relatively strongly is called "dualists", and more than a quarter (27.5\%) of the subjects fell into this statistical type. The attitude structure of these individuals exhibits a dualistic nature which shows that their opinion on national identity is ambiguous. Strongly expressed components of both attitudes give grounds for believing that in terms of nationality, this is a rather flexible type. The largest group of subjects is characterized by a weakly exhibited outlook on national identity. It was neutral towards national identity and was therefore named as the "indifferent" (36.3\%) group.

In 2008, statistical types of students were also identified according to their "modern" and "traditional" outlooks on national identity (see Figure 3). 


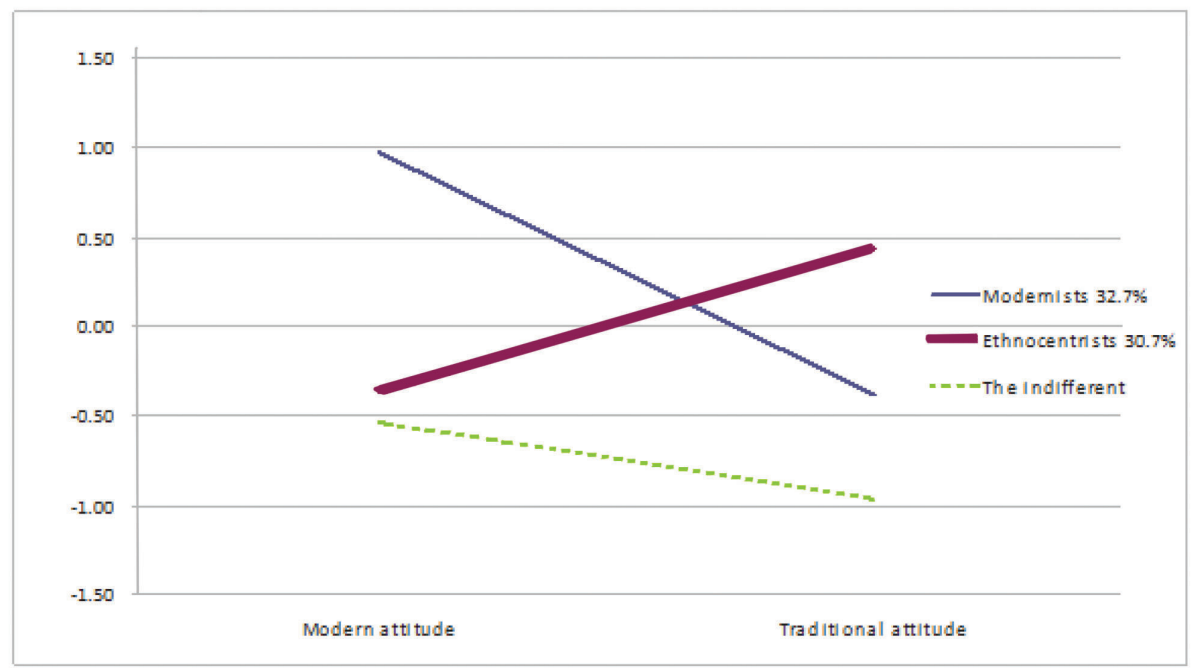

Figure 3. Statystical types of students, classified by their either modern or traditional approach to national identity (2008 year).

Clustering results obtained in 2008 are presented in Figure 3. In the 2008 study, the construction of various models (with two, three, or four clusters) was attempted. In this case, a three-cluster model appeared to be the most suitable. The results show that, unlike the previous study, there are only three different groups of studying youth, according to outlook on national identity. These groups were also named as "indifferent", "modernist", and "ethnocentrist". The proportion of "indifferent" students remained almost the same, i.e. 36.6\%, of "modernists" and "ethnocentrists" at $32.7 \%$ and $30.7 \%$, respectively. Unlike in the data of the previous study, the group that had previously been held to be the most flexible regarding national identity - the "dualists" - was no longer present.

In the 2018 study, after trying various cluster models, four types of subjects were identified, just as in the first study: "modernists" (21.4\%), "dualists" (23.3\%), "ethnocentrists" (22.0\%), and "indifferent" (33.3\%). The statistical types of academic youth are shown in Figure 4.

Even though, as can be seen in Figures 2 and 4, the percentage distribution of academic youth statistical types changed slightly, the overall distribution remained similar.

Thus, the cluster analysis revealed sufficiently characteristic and meaningful interpretations of statistical types according to nationality. The received profiles are very contrasting and this is one of the valid arguments for the statistical types found. 


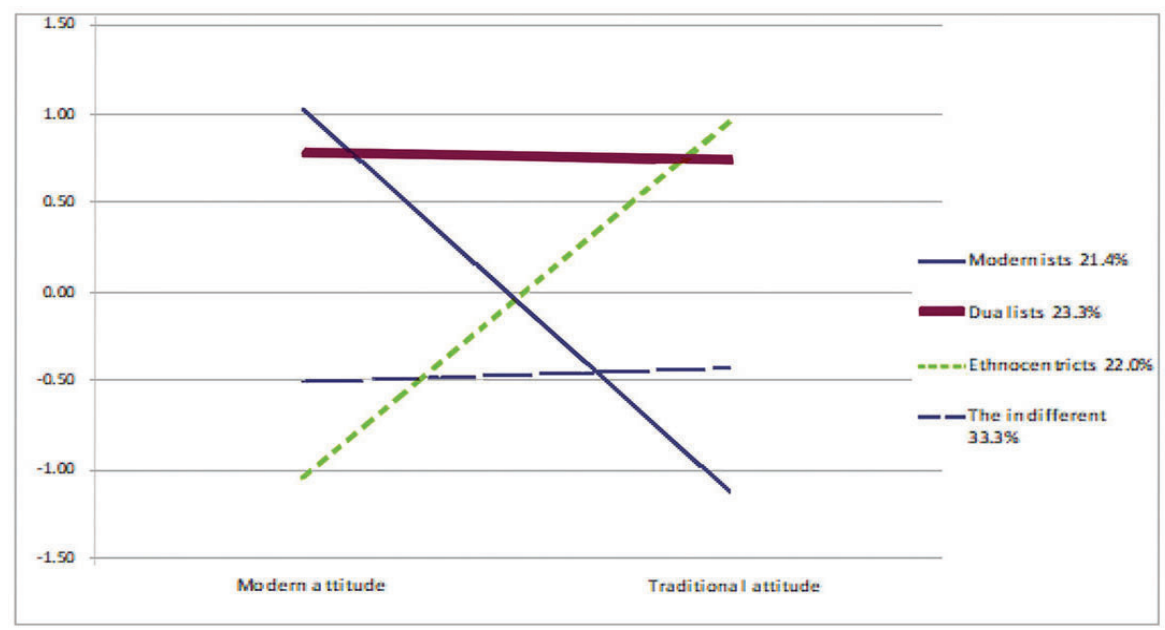

Figure 4. Statystical types of students, classified by their either modern or traditional approach to national identity (2018 year)

The study showed that national identity can be considered a complex and multidimensional construct. Factor analysis revealed that a national identity scale can be very wide, starting from an extreme national chauvinism that emphasizes national exclusivity to cosmopolitanism that neglects national culture, traditions, patriotism, etc. Five main indexes of national identity attitudes were distinguished by the study: "ethnocentrism", "nationalism", "moderate and rational approach", "reflective and democratic approach" and "anti-ethnocentrism (conditional cosmopolitanism)". The multistage factor analysis model also suggested the possibility of polarization of national identity attitudes into two constituents of "traditional" (including "ethnocentrism", "nationalism", "moderate and rational approach"), and "modern" nationality (including "reflective and democratic approach" and "anti-ethnocentrism").

Further analysis of the data revealed that national identity attitudes among young adults in Lithuania have undergone changes between 2003-2018. The study showed that from 2003-2018 ethnocentrism and a moderate approach to nationality have increased, whereas extreme attitudes, such as nationalism and anti-ethnocentrism (cosmopolitanism), have decreased.

In general, the traditional conservative attitudes towards national identity declined from $50.4 \%$ in 2003 to $46.0 \%$ in 2008 and rose again to $53.8 \%$ in 2018 . Recently, traditional conservative attitudes towards national identity gained the greatest significance. In Table 6 , it can be seen in detail that despite the decline of a nationalistic aspect in a traditional approach, ethnocentric, moderate and rational attitudes have increased. The change of ratings on the ethnocentrism scale is especially pronounced: the high mean rank in 2003 fell sharply in 2008 and rose again in 2018. Such "dip" effects were not identified on other 
scales. Because changes in national identity can be tied to the geopolitical landscape, one possible explanation can be associated with fundamental changes in the relationship between Lithuania and an important neighbour, Russia, in 2008-2009. As noted by Denisenko (2016), after examining Russian periodicals which wrote about the Baltic States from 1991-2009, an obvious breaking point was in 2008-2009, when, after the breakout of the Russo-Georgian war, Lithuania, Latvia, and Estonia took a clear position and even then, called for sanctions against Russia. Even though the Baltic states were not heard in the West, in Moscow their position was understood. According to Denisenko (2016), since then any positive statements about the Baltic states in the Russian press are hard to find, and that's when a negative attitude towards the Baltic states was formed, which was undoubtedly noticed in the Baltic states themselves. Therefore, it is likely that ethnocentrism started to increase as a response to the rising tensions. Subsequent aggressive Russian actions in Ukraine in 2014 could have strengthened these attitudes even more, and this can be explained by noticing that since the beginning of this conflict, the perceived security of Lithuanian citizens regarding the conflict was reported as low (Gečienè, 2013). A detailed analysis of the Russian press carried out by Denisenko (2016), allows for the assumption of explanations as to why the mean ranks of ethnocentrism declined drastically from 2003-2008. According to the scientist, in 2000 nobody saw Putin as a potential authoritarian leader; in 2001 Russia supported the USA in the fight against terrorism. Even during 2003-2004, when the Baltic states joined NATO, there was no significant negative attitude jump. From the look at the scientific publications, it can be said that Russia was not against the Baltic countries joining NATO. It was like a sign that relations with Russia were fine. This decreasing tension was likely to be the factor for the decreasing ethnocentrism among Lithuanians. The importance of a political situation for national identity constructions is also pointed out in other studies - after the collapse of the Soviet Union, the national identity concept of Ukrainians transformed into a more ethnic-based one; they began to support the idea of creating Ukraine specifically for ethnic Ukrainians, not a multi-ethnic Ukraine (Korostelina, 2003).

The results of the study may be also linked with significant globalization process changes that happened in the world from 2003 to 2018. On one hand, accelerating globalization opened up borders between nations, on the other hand, it caused a lot of problems in politics, economy, culture, social sphere etc. One of the characteristics of this phenomenon is the decline of countries' sovereignty, which provoked an active tide of antiglobalism rolling through the wold in recent times. These processes happening in politics and society unquestionably affect people's identity.

Significant changes of other scales' mean ranks could be also explained within the same context. As the results indicate, modern attitudes ("reflective and democratic approach" and "anti-ethnocentrism" (conditional cosmopolitanism)) towards national identity in our study increased from $48.3 \%$ in 2003 to $54.0 \%$ in 2008 and decreased again to $46.2 \%$ in 2018 . Questions about the relationship between national identity and 
globalization have been raised in the scientific literature. One study analyzing data from sixty-three countries investigated how a country's level of globalization is related to its public perceptions of different dimensions of national identity (Ariely, 2012). Though the study didn't find associations between a country's level of globalization and national identification or nationalism, it related negatively to patriotism the willingness to fight for the country and ethnic conceptions of membership in the nation.

Throughout the period of the study (2003-2018), a reduction in extreme viewpoints (nationalism and anti-ethnocentrism) and an increase in moderate attitudes (see Table 6) has been recorded, which leads to the conclusion that the studying youth have been becoming more rational regarding national identity over the past decade, and less likely to only see black and white. At the same time, a question can be raised: how much of this process is consciously understood by the personality itself, as the study shows that national identity reflection gradually decreased in 2003-2018. This means that one of the most important aspects of national identity - a conscious understanding of one's own national identity, its contemplation - is gradually weakening.

The study also revealed that young adults can be associated with different types of national identity and some of them integrate different attitudes. Using cluster analysis, four statistical types of Lithuanian students' national attitudes were distinguished. Our study revealed that academic youth can be divided into four groups according to their national identity attitudes: dualists, an indifferent group, modernists and ethnocentrists. In 2018, both the modernist and ethnocentrist groups accounted for similar parts of the academic youth - one out of five young people belong to one of these two groups.

Another part of young people was assigned to the "indifferent group" according to their national identity views, which means that national identity is not an important part of their own identity and belief system. Studies in 2003 and 2008 revealed that $36 \%$ of respondents belonged to this group, and in 2018 the percentage declined slightly to approximately $33 \%$. However, another study of Lithuanian national identity in the European context revealed that $87 \%$ of students agreed with a statement that being Lithuanian is important to the way they think of themselves as persons (Hoffman, 2013).

Also, in 2003 and 2018, 27.5\% and 23.3\% of the respondents respectively were assigned to the "dualist" group as they possessed both "modern" and "traditional" views towards national identity. The existence of a dualistic group indicates that the modern and traditional attitudes that reflect national identity are combined with each other. Increasing young people's mobility, free international mobility opportunities, and joining the European Union and NATO might be important factors that encourage the prevalence of modern attitudes; however, the study shows that at the same time traditional attitudes can also be preserved. The Eurobarometer survey also showed that national and European identity can be integrated as 53\% of Lithuanians identify both with European and Lithuanian nationality (Eurobarometer, 2014). 
Our study has shown that national identity is a complex phenomenon which is not easy to measure. Different authors highlight different national identity types because they use different methodologies. For example, a recent study distinguished three forms of Lithuanian national identity followed by young Lithuanians, two of which are ethnic in nature, while the third is civic: the "autonomous ethnic nationalism" which is largely defined according to ethno-linguistic characteristics; the "embedded ethnic nationalism" which demonstrates the respondents' feelings of connection to the broader community; and the "civic" identity which indicates that a Lithuanian citizen is someone who respects the state's institutions and laws, supports democratic values like freedom and equality, and supports the sovereign independence of Lithuania (Buhr et al., 2014). This suggests that national identity can be analyzed from different perspectives and that national identity as a phenomenon is not static. This extends to the notion that studies in this field conduct actual analysis and need thorough analysis. Some implications for future research should also be mentioned. Since our study revealed that attitudes that reflect national identity among young people keep changing over time, it is important in the future to carry out longitudinal studies, observing the same samples and how stable their attitudes are. It is also important to analyze what demographic factors and personal qualities are related to the expression of different national identity attitudes and types.

\section{Conclusions}

Factor analysis revealed that a national identity scale can be very wide, starting from an extreme national chauvinism that emphasizes national exclusivity to cosmopolitanism that neglects national culture, traditions, patriotism, etc. The study showed that national identity as a phenomenon is not static: from 2003-2018 ethnocentrism and a moderate approach to nationality have increased, whereas extreme attitudes, such as nationalism and anti-ethnocentrism (cosmopolitanism), have decreased. Using cluster analysis, four statistical types of Lithuanian students' national attitudes were distinguished. The study revealed that academic youth can be divided into four groups according to their national identity attitudes: dualists, an indifferent group, modernists and ethnocentrists.

\section{References}

Abell, J., Condor, S., \& Stevenson, C. (2006). 'We are an Island': Geographical Imagery in Accounts of Citizenship, Civil Society, and National Identity in Scotland and in England. Political Psychology, 27(2), 207-226.

Antiniené, D. (2012). Attitudes Reflecting National Identity of Lithuanian Students. Humanities and Social Sciences Latvia, 20(1), 4-22. 
Ariely, G. (2012). Globalisation and the Decline of National Identity? An Exploration Across Sixty-Three Countries. Nations and Nationalism, 18(3), 461-482.

Ariely, G. (2019). National Days, National Identity, and Collective Memory: Exploring the Impact of Holocaust Day in Israel. Political Psychology, 40(6), 1391-1406. doi: 10.1111/pops.12595. Retrieved from: https://onlinelibrary-wiley-com.ezproxy.dbazes.lsmuni.lt/doi/epdf/10.1111/pops.12595

Borg, I., \& Gabler, S. (2002). Zustimmungsanteile und Mittelwerte von Likert-skalierten. Social Science open Access Repository, 7-25.

Brylka, A., Mähönen, T. A., \& Jasinskaja-Lahti, I. (2015). National Identification and Intergroup Attitudes Among Members of the National Majority and Immigrants: Preliminary Evidence for the Mediational Role of Psychological Ownership of a Country. Journal of Social and Political Psychology, 3(1), 24-45.

Brown, D. (2007). Ethnic Conflict and Civic Nationalism: A model. In Peacock, J., Thornton, P. M., Inman P. I. (Eds.) Identity matters. New York: Berghahn.

Buhr, R., Fabrykant, M. S., \& Hoffman, S. M. (2014). The Measure of a Nation: Lithuanian Identity in the New Century. Journal of Baltic Studies, 45(2), 143-168.

Carvalho, S. W., Lunab, D., \& Goldsmith, E. (2019). The Role of National Identity in Consumption: An Integrative Framework. Journal of Business Research, 103, 310-318. Retrieved from: https:// www.journals.elsevier.com/journal-of-business-research

Cote, J. M., \& Levine, C. G. (2008). Identity, Formation, Agency and Culture: A Social Psychological Synthesis. New York: Taylor \& Francis e-Library.

Denisenko, V. (2016). Du madingiausi Rusijoje mitai apie Baltijos valstybes (Two most fashionate myths in Russia about Baltic states). Retrieved from: http://www.delfi.lt/news/daily/lithuania/ du-madingiausi-rusijoje-mitai-apie-baltijos-valstybes.d?id=70625116

Dekker, H., Malova, D., \& Hoogendorn, S. (2003). Nationalism and Its Explanations. Political Psychology, 24(2), 345-377.

Eurobarometer (2014). Standard Eurobarometer 81, Spring 2014. Retrieved from: http://ec.europa. eu/public_opinion/archives/eb/eb81/eb81_anx_en.pdf

Fligstein, N., Polyakova, A., \& Sandholtz, W. (2012). European Integration, Nationalism and European Identity. JCMS: Journal of Common Market Studies, 50(1), 106-122.

Gečienė, I. (2015). Lietuvos gyventojų subjektyvus saugumo suvokimas išorinių grèsmių kontekste (Subjective Perception of Security by the Lithuanian People in the Context of External Threats). Kultūra ir visuomene: Socialinių tyrimų žurnalas, 6(1), 55-69.

Grigas, R. (2001). Tautine savivoka. Vilnius: Rosma.

Hanson, K., \& O’Dwyre, E. (2019). Patriotism and Nationalism, Left and Right: A Q-Methodology Study of American National Identity. Political Psychology, 40(4), 777-795. doi: 10.1111/ pops.12561. Retrieved from: https://onlinelibrary-wiley-com.ezproxy.dbazes.lsmuni.lt/doi/ epdf/10.1111/pops.12561

Hoffman, S. M., Fabrykant, M., \& Buhr, R. (2013). Youth and National Identity in Belarus and Lithuania: a Comparative Analysis. Chapter 7. In: Buhr, R., Fabrykant, M., Hoffman, S., Jasiuleviciene, R., Mazylis, L., Rakutiene, S., Shadurski, V., Tsikhamirau, A., \& Venclauskas, L. Lithuanian and 
Belarusian National Identity in the Context of European Intergration (pp. 182-198). Kaunas: Vytautas Magnus University.

Korostelina, C. (2003). The Multiethnic State-Building Dilemma: National and Ethnic Minorities' Identities in the Crimea. National Identities, 5(2), 141-159.

Korostelina, K. (2008). Concepts of National Identity and the Readiness for Conflict Behaviour. National Identity, 10(2), 207-223.

Kosterman, R., \& Feshbach, S. (1989). Toward a Measure of Patriotic and Nationalistic Attitudes. Political Psychology, 10(2), 257-274.

Lantz, G., Loeb, S., Nguyen, T., \& Van Khanh, T. (2002). National Identity, Consumer Ethnocentrism and Product Preferences in Vietnam. Asia Pacific Advances in Consumer Research, 5, 169-173.

Mazylis, L. (2013). Lithuania's European Identity during the Post-Soviet Period. Chapter 4. In: Buhr, R., Fabrykant, M., Hoffman, S., Jasiuleviciene, R., Mazylis, L., Rakutiene, S., Shadurski, V., Tsikhamirau, A., \& Venclauskas, L. Lithuanian and Belarusian National Identity in the Context of European Intergration (pp. 124-138). Kaunas: Vytautas Magnus University.

Le, N. H., Thi Nguyen, H. M., \& Van Nguyen, T. (2013). National Identity and the Perceived Values of Foreign Products with Local Brands: The Case of Local Wine in Vietnam. Asia Pacific Journal of Marketing and Logistics, 25(5), 765-783.

Petzold, T. D., \& Lehmann, N. (2011). Salutogenesis, Globalization, and Communication. International Review of Psychiatry, 23(6), 565-575.

Phinney, J. S. (1990). Ethnic Identity in Adolescents and Adults: Review of Research. Psychological Bulletin, 108(3), 499-514.

Rakauskienè, O., \& Ranceva, O. (2013). Threat of Emoiration for the Socio-Economis Development of Lithuania. Business, Management \& Education / Verslas, Vadyba ir Studijos, 11, 77-95.

Ray, S. (2018). Ethnic Inequality and National Pride. Political Psychology, 39(2), 263-280. doi: 10.1111/pops.12406. Retrieved from: https://onlinelibrary-wiley-com.ezproxy.dbazes.lsmuni. lt/doi/epdf/10.1111/pops.12406

Rembold, E., \& Carrier, P. (2011). Space and Identity: Constructions of National Identities in an Age of Globalization. National Identities, 13(4), 361-377.

Sadowski, A. (2008). II National Identity the Process of the Construction of the National Identities on the Polish-Lithuanian-Belarusian Borderland. LIMES: Cultural Regionalistics, 1(1), 46-54.

Sipavičienè, A., \& Stankūnienè, V. (2011). Lietuvos gyventojų (e)migracijos dvidešimtmetis: tarp laisvès rinktis ir išgyvenimo strategijos (Two Decades of Emigration from Lithuania: Between Free Choice and Survival Strategy). Filosofija. Sociologija, 22(4), 323-333.

Kuper, A., \& Kuper, J. (Eds.) (2002). The Social Science Encyclopedia. New York: Rotledge.

Yogeeswaran, K., \& Dasgupta, N. (2014) Conceptions of National Identity in a Globalised World: Antecedents and Consequences. European Review of Social Psychology, 25(1), 189-227.

Zhuojun, W., \& Hualing, H. (2014) National Identity in the Era of Globalization: Crisis and Reconstruction. Social Sciences in China, 35(2), 139-154. 


\title{
Lietuvos akademinio jaunimo tautinio tapatumo raiška ir
}

\section{kaita}

\author{
Dalia Antiniené ${ }^{1}$, Giedrè Širvinskienè $\dot{e}^{1,2}$, Rosita Lekavičiené ${ }^{3}$
}

1 Lietuvos sveikatos mokslų universitetas, Visuomenės sveikatos fakultetas, Tilžés g. 18, 47181 Kaunas, dalia.antiniene@lsmuni.lt, giedre.sirvinskiene@lsmuni.lt

2 Lietuvos sveikatos mokslų universitetas, Sveikatos tyrimų institutas, Tilžès g. 18, 47181 Kaunas, giedre.sirvinskiene@lsmuni.lt

3 Kauno technologijos universitetas, Socialinių, humanitarinių mokslų ir menu fakultetas, A. Mickevičiaus g. 37 , 44244 Kaunas, rosita.lekaviciene@ktu.lt

\section{Santrauka}

Visuomenè tampa vis labiau daugiasluoksnè, todèl tautinio tapatumo sąvokos traktuotė nuolat kinta ir igyja naujas prasmes. Modernioje visuomeneje tapatumo samprata darosi problemiška, sudètinga ir patiria krizę politiniu, ekonominiu ir kultūriniu lygmeniu. Šis straipsnis skirtas Lietuvos akademinio jaunimo tautinio identiteto nuostatų raiškos ir kaitos analizei. Tyrimas buvo atliekamas 2003, 2008 ir 2018 m. Tautiškumo nuostatos tirtos naudojant originalų anoniminị uždaro tipo klausimyną. Rezultatai parodè, kad tautinio tapatumo skale gali būti labai plati, pradedant nuo ekstremalaus nacionalšovinizmo, pabrèžiančio nacionalinị išskirtinumą, iki kosmopolitizmo, ignoruojančio nacionalinę kultūrą, tradicijas ir patriotizmą. Daugiapakopès faktorinès analizès būdu nustatyta tautinio tapatumo vidaus struktūra: etnocentrizmas, nacionalizmas, nuosaikusis / racionalusis, refleksyvusis / demokratinis požiūris ir antietnocentrizmas. Empirinio tyrimo duomenys atskleidè, jog tautinị tapatumą atspindinčios nuostatos gana aiškiai poliarizuojasi ị du požiūrị ị tautiškumą atspindinčius komponentus modernų (apimantị etnocentrizmą, nacionalizmą ir nuosaikų / racionalųjị) ir tradicinị (apimantị refleksyvų / demokratinị ir antietnocentristinị). Nustatyta, jog 2003-2018 m. laikotarpiu Lietuvos akademinio jaunimo tautinis tapatumas pakito: nustatyta dažnesnè etnocentrizmo ir nuosaikiojo / racionaliojo požiūrio raiška, o kraštutiniai požiūriai, t. y. nacionalizmas ir antietnocentrizmas (kosmopolitizmas), sumenko.

Esminiai žodžiai: tautinis tapatumas, nuostatos, nacionalizmas, tradicinis tautiškumas, šiuolaikinis tautiškumas, etnocentrizmas, antietnocentrizmas. 